\title{
Liste des habilitations à la direction de recherches soutenues à la section pendant l'année 2008-2009
} par ordre alphabétique des noms d'auteur

\section{OpenEdition}

\section{Journals}

Édition électronique

URL : https://journals.openedition.org/ashp/952

DOI : 10.4000/ashp.952

ISSN : 1969-6310

Éditeur

Publications de l'École Pratique des Hautes Études

Édition imprimée

Date de publication : 2 février 2011

Pagination : xiv

ISSN : 0766-0677

Référence électronique

"Liste des habilitations à la direction de recherches soutenues à la section pendant l'année 2008-2009 », Annuaire de l'École pratique des hautes études (EPHE), Section des sciences historiques et philologiques [En ligne], 141 | 2011, mis en ligne le 22 février 2011, consulté le 06 juillet 2021. URL http://journals.openedition.org/ashp/952 ; DOI : https://doi.org/10.4000/ashp.952

Ce document a été généré automatiquement le 6 juillet 2021.

Tous droits réservés : EPHE 


\section{Liste des habilitations à la direction de recherches soutenues à la section pendant l'année 2008-2009}

par ordre alphabétique des noms d'auteur

1 Hommes du roi et princes de l'Église romaine : la réception des modèles italiens dans le mécénat des cardinaux français (1495-1560), par Flaminia BARDATI, sous la direction de $\mathrm{M}^{\text {me }}$ Sabine FROMMEL, le $1^{\text {er }}$ décembre 2008.

2 Autour de Guillaume l'Anglais. Recherches sur l'uroscopie médiévale, par Laurence MOULINIERBROGI, sous la direction de $\mathrm{M}^{\text {me }}$ Danielle JACQUART, le 29 novembre 2008.

3 Au-delà des cités. Territoires et formes d'organisation politique et sociale dans le monde grec de l'époque classique à l'époque impériale, par Christel MÜLLER, sous la direction de M. JeanLouis FERRARY, le 29 novembre 2008. 